\title{
Association between arterial stiffness and pulmonary function in hypertensive patients
}

\begin{abstract}
Hisashi Masugata ${ }^{1}$, Shoichi Senda ${ }^{1}$, Hiroki Okada ${ }^{2}$, Koji Murao $^{3}$, Michio Inukai ${ }^{1}$, Takashi Himoto ${ }^{1}$, Naohisa Hosomi ${ }^{4}$, Kazushi Murakami ${ }^{5}$, Takahisa Noma $^{5}$, Masakazu Kohno ${ }^{5}$ and Fuminori Goda ${ }^{1}$

Arterial stiffness, assessed by cardio-ankle vascular index (CAVI), is clinically used to assess arteriosclerosis. Recently, pulmonary age, as determined by pulmonary function test, has been proposed by the Japanese Respiratory Society as a diagnostic measure for chronic obstructive pulmonary disease (COPD). This study aims to examine the association between CAVI and pulmonary function and to elucidate the correlation between vascular stiffness and pulmonary age in hypertensive patients. We enrolled a total of 45 hypertensive patients ( $70 \pm 9$ years) who had been taking antihypertensive medications for at least 1 year. Pulmonary function was measured by the percentage of predicted forced vital capacity (FVC) and the ratio of forced expiratory volume in $1 \mathrm{~s}\left(\mathrm{FEV}_{1}\right)$ to $\mathrm{FVC}\left(\mathrm{FEV}_{1} / \mathrm{FVC}\right.$ ratio). Pulmonary age was determined by the equation proposed by the Japanese Respiratory Society. CAVI was measured at the same clinic visit. In the simple correlation analysis CAVI correlated with the $\mathrm{FEV}_{1} / \mathrm{FVC}$ ratio $(r=-0.399, P=0.007)$ and pulmonary age $(r=0.559, P<0.001)$. Multiple linear regression analysis revealed that CAVI was independently associated with $\mathrm{FEV}_{1} / \mathrm{FVC}$ ratio $(\beta=-0.418, P=0.014)$ and pulmonary age $(\beta=0.514$, $P=0.002$ ). In addition, CAVI was significantly higher in patients with increased pulmonary age (9.4 \pm 1.4$)$ than in those with normal pulmonary age $(8.4 \pm 0.9)(P=0.011)$. The present study indicates that an increased CAVI is independently associated with reduced pulmonary function and increased pulmonary age. Hypertensive patients with high CAVI may need to be monitored for the progression of COPD.
\end{abstract}

Hypertension Research (2012) 35, 388-392; doi:10.1038/hr.2011.199; published online 24 November 2011

Keywords: cardio-ankle vascular index; pulmonary age; pulmonary function

\section{INTRODUCTION}

Arterial stiffness is attracting attention as an index for assessing arteriosclerosis, as it is an independent predictor of cardiovascular mortality, fatal and non-fatal coronary events, and fatal strokes in hypertensive patients. ${ }^{1,2}$ The cardio-ankle vascular index (CAVI) is a new index of arterial stiffness. ${ }^{3}$ As the most conspicuous feature of CAVI is a lack of dependence on blood pressure, CAVI has been recently utilized for assessing arterial stiffness in clinical settings. ${ }^{4}$ CAVI is high in aging patients and in patients with arteriosclerotic disease, such as coronary artery disease, ${ }^{5}$ carotid atherosclerosis ${ }^{6}$ and chronic kidney disease, ${ }^{7}$ and is related to many coronary risk factors such as hypertension, ${ }^{8}$ diabetes, ${ }^{9}$ dyslipidemia ${ }^{9}$ and smoking. ${ }^{10}$ Furthermore, the CAVI decreases with control of diabetes and hypertension, as well as abstention from smoking. ${ }^{10}$ These factors suggest that CAVI is a surrogate marker of arteriosclerosis.

Chronic obstructive pulmonary disease (COPD) is characterized by chronic airflow limitation, which shows reduced forced expiratory volume in $1 \mathrm{~s}\left(\mathrm{FEV}_{1}\right)$ in pulmonary function tests. ${ }^{11,12}$ Recent studies have demonstrated an association between COPD and cardiovascular disease, which accounts for approximately 25 to $50 \%$ of mortality. ${ }^{13-15}$ Furthermore, recent studies ${ }^{16-19}$ have demonstrated the association between pulmonary function and carotid atherosclerosis. These previous studies ${ }^{16-19}$ assessed the atherosclerosis by measuring carotid intima-media thickness and plaques. Other previous studies ${ }^{20,21}$ have demonstrated the association between pulmonary function and atherosclerosis by measuring arterial stiffness, which was assessed by aortic pulse wave velocity. Although CAVI measures arterial stiffness, CAVI is different from aortic pulse wave velocity as CAVI reflects the stiffness of the aorta, femoral artery and tibial artery as a whole. ${ }^{22}$

Recently, 'pulmonary age' has been proposed by the Japanese Respiratory Society in order to diagnose COPD. ${ }^{23}$ Pulmonary age is determined based on the pulmonary function test, including the forced vital capacity (FVC) and $\mathrm{FEV}_{1}$. Pulmonary age is known to be high in COPD patients. ${ }^{23}$ This study aims to examine the association between arterial stiffness assessed by CAVI and pulmonary function in hypertensive patients. Moreover, we seek to elucidate the correlation between pulmonary age assessed by pulmonary function test and vascular stiffness assessed by CAVI in hypertensive patients.

${ }^{1}$ Department of Integrated Medicine, Kagawa University, Kagawa, Japan; ${ }^{2}$ Department of Medical Education, Kagawa University, Kagawa, Japan; ${ }^{3}$ Department of Advanced Medicine and Laboratory Medicine, Kagawa University, Kagawa, Japan; ${ }^{4}$ Department of Clinical Neuroscience and Therapeutics, Hiroshima University Graduate School of Biomedical Sciences, Hiroshima, Japan and ${ }^{5}$ Department of Cardiorenal and Cerebrovascular Medicine, Kagawa University, Kagawa, Japan 


\section{METHODS}

\section{Subjects and protocol}

The study subjects were 45 hypertensive outpatients ( 24 male, 21 female; mean age $70 \pm 9$ years, range 47-84 years) at Kagawa University Hospital who were diagnosed with hypertension. All had been taking antihypertensive medications for at least 1 year. Hypertension was defined as systolic blood pressure $\geqslant 140 \mathrm{~mm} \mathrm{Hg}$ and/or diastolic blood pressure $\geqslant 90 \mathrm{~mm} \mathrm{Hg}$. Patients on hemodialysis or with a history of heart failure or ischemic heart disease were excluded. Patients with renal impairment, defined by clinically abnormal serum creatinine $>2.0 \mathrm{mg} \mathrm{dl}^{-1}$, were also excluded. None of the subjects had a history of any atherosclerotic cardiovascular disease or stroke. Blood pressure was determined using the conventional cuff method at the time when the pulmonary function test was performed. Pulmonary function tests were performed for all participants. Before pulmonary function tests, blood examination and measurement of CAVI were performed. Relationships among clinical characteristics, including blood pressure and laboratory data, CAVI and parameters of pulmonary function test, were analyzed. This protocol was approved by the Ethics Committee of Kagawa University. Informed consent was obtained from all participants.

\section{Blood examinations}

Blood sampling was performed in the morning after a 12-h overnight fast. Plasma total cholesterol, triglyceride, high-density lipoprotein cholesterol, creatinine, high-sensitivity C-reactive protein (hsCRP) and WBC count were measured by standard laboratory techniques. Plasma hsCRP level was measured using a latex particle-enhanced immunoassay with the nephelometry method.

\section{Measurement of CAVI}

CAVI was recorded using a VaseraVS-1000 vascular screening system (Fukuda Densi, Tokyo, Japan) with the patient resting in a supine position. The principal underlying CAVI has been described previously. ${ }^{3}$ ECG electrodes were placed on both wrists, a microphone for detecting heart sounds was placed on the sternum and cuffs were wrapped around both arms and both ankles. Blood pressure was measured after detecting the pulse.

CAVI is determined by the following equation:

$$
\mathrm{CAVI}=\mathrm{a}\left\{(2 \rho / \Delta \mathrm{P}) \times \ln (\mathrm{Ps} / \mathrm{Pd}) \mathrm{PWV}^{2}\right\}+\mathrm{b},
$$

where Ps and Pd are systolic blood pressure and diastolic blood pressure, respectively, $\mathrm{PWV}$ is pulse wave velocity from the origin of the aorta to the junction of the tibial artery with the femoral artery, $\Delta \mathrm{P}$ is Ps-Pd, $\rho$ is blood density and $\mathrm{a}$ and $\mathrm{b}$ are constants. The equation is derived from Bramwell-Hill's equation and the stiffness parameter $\beta$, and CAVI was adjusted for blood pressure based on the stiffness parameter $\beta$. Therefore, CAVI reflects the stiffness of the aorta, femoral artery and tibial artery as a whole; theoretically, it is not affected by blood pressure. After automatic measurements, the obtained data were analyzed using VSS-10 software (Fukuda Densi), and the values of right and left CAVI were calculated. The average of the right and left CAVIs was used for analysis. The average coefficient of variation of CAVI in our laboratory was $3.9 \%$, which was sufficiently low for clinical usage and indicated that CAVI had good reproducibility.

\section{Pulmonary function test}

Pulmonary function tests were performed using a computed spirometer (DISCOM-21FX, CHEST M.I., Tokyo, Japan). The tests were performed with the subject in a sitting position and with noseclips in place. FVC and $\mathrm{FEV}_{1}$ from the best tests, as defined by the American Thoracic Society, ${ }^{24}$ were recorded. Published prediction equations were used to calculate predicted $\mathrm{FVC}$ and $\mathrm{FEV}_{1}$ for each subject. Percentages of predicted FVC and $\mathrm{FEV}_{1}$ were calculated. The ratio of $\mathrm{FEV}_{1}$ to $\mathrm{FVC}\left(\mathrm{FEV}_{1} / \mathrm{FVC}\right)$ was also calculated. Finally, pulmonary age for screening COPD was calculated based on sex, age, height, FVC and $\mathrm{FEV}_{1}$ of each subject by using the equation proposed by the Japanese Respiratory Society. ${ }^{23}$ The obtained pulmonary age divided the subjects into two groups: 20 hypertensive patients with normal pulmonary age, whose pulmonary age was less than or equal to their real age, and 25 hypertensive patients with increased pulmonary age, whose pulmonary age was greater than their real age.

\section{Statistical analysis}

Data are expressed as means \pm s.d. Statistical analysis was performed using the SPSS software package (SPSS, Chicago, IL, USA). Linear regression analysis was performed to evaluate the association between parameters of the pulmonary function test, CAVI, and other variables. Stepwise multiple regression analysis was performed to identify the independent determinants of the parameters of the pulmonary function test. Comparisons were made between patients with normal and increased pulmonary ages using unpaired $t$-tests for continuous variables and $\chi^{2}$ analyses for categorical data. Values of $P<0.05$ were considered to indicate statistical significance.

\section{RESULTS}

\section{Clinical characteristics of subjects}

The clinical and spirometric parameters of the subjects are summarized in Table 1 . The percentage $(73 \%)$ of subjects prescribed calcium channel blockers was highest among those who were also taking antihypertensive drugs. Mean values of systolic $(131 \pm 14 \mathrm{~mm} \mathrm{Hg})$ and diastolic $(79 \pm 8 \mathrm{~mm} \mathrm{Hg}$ ) blood pressure were not high because the blood pressure of the participants was well controlled.

\section{Association between parameters of pulmonary function test and other variables}

Linear regression analysis was performed to examine the relationship between parameters of the pulmonary function test and other variables in all subjects (Tables 2, 3, 4, and 5). The percentage of predicted

\section{Table 1 Clinical characteristics of the patients}

\begin{tabular}{|c|c|}
\hline Number (male/female) & $45(24 / 21)$ \\
\hline Age (years) & $69.6 \pm 9.4$ \\
\hline BMI $\left(\mathrm{kg} \mathrm{m}^{-2}\right)$ & $24.2 \pm 3.4$ \\
\hline Diabetes mellitus $(n(\%))$ & $8(18)$ \\
\hline Dyslipidemia $(n(\%))$ & $17(38)$ \\
\hline Current smoker ( $(\%))$ & $7(16)$ \\
\hline \multicolumn{2}{|l|}{ Antihypertensive drugs } \\
\hline ARB/ACEI $(n(\%))$ & $24(53)$ \\
\hline $\operatorname{CCB}(n(\%))$ & $33(73)$ \\
\hline$\beta$-Blockers $(n(\%))$ & $13(29)$ \\
\hline Diuretics $(n(\%))$ & $7(16)$ \\
\hline Systolic BP (mm Hg) & $131 \pm 14$ \\
\hline Diastolic BP $(\mathrm{mm} \mathrm{Hg})$ & $79 \pm 8$ \\
\hline Heart rate (beats per min) & $63 \pm 10$ \\
\hline Total cholesterol ( $\mathrm{mg} \mathrm{dl}^{-1}$ ) & $195 \pm 28$ \\
\hline HDL cholesterol (mg dl-1) & $52 \pm 12$ \\
\hline Triglycerides $\left(\mathrm{mg} \mathrm{dl}^{-1}\right)$ & $137 \pm 78$ \\
\hline Hemoglobin $\left(\mathrm{g} \mathrm{dl}^{-1}\right)$ & $13.1 \pm 1.6$ \\
\hline Creatinine $\left(\mathrm{mg} \mathrm{dl}^{-1}\right)$ & $0.75 \pm 0.21$ \\
\hline White cell count (cells per $\mu$ l) & $5894 \pm 1665$ \\
\hline $\operatorname{hsCRP}\left(\mathrm{mg} \mathrm{dl}^{-1}\right)$ & $0.17 \pm 0.19$ \\
\hline CAVI & $9.0 \pm 1.3$ \\
\hline
\end{tabular}

\section{Pulmonary function}

FVC (I)

$2.70 \pm 0.71$

Percentage of predicted FVC (\%)

$96.9 \pm 16.0$

$\mathrm{FEV}_{1}$ (I)

$2.12 \pm 0.63$

Percentage of predicted $\mathrm{FEV}_{1}(\%)$

$106.8 \pm 22.6$

$\mathrm{FEV}_{1} / \mathrm{FVC}$ ratio

$78.5 \pm 9.9$

Pulmonary age (years)

Abbreviations: ACEI, angiotensin-converting enzyme inhibitors; ARB, angiotensin II receptor blockers; BMI, body mass index; BP, blood pressure; CAVI, cardio-ankle vascular index; blockers; BMI, body mass index; BP, blood pressure; CAVI, cardio-ankle vascular index;
$\mathrm{CCB}$, calcium channel blockers; $\mathrm{FEV}_{1}$, forced expiratory volume in $1 \mathrm{~s} ; \mathrm{HDL}$, high-density lipoprotein; hsCRP, high-sensitivity C-reactive protein. 
Table 2 Correlations between clinical parameters and the percentage of predicted FVC

\begin{tabular}{|c|c|c|c|c|}
\hline & \multicolumn{2}{|c|}{ Univariate } & \multicolumn{2}{|c|}{ Multivariate } \\
\hline & $r$ & $\mathrm{P}$ value & $\beta$ & $\mathrm{P}$ value \\
\hline Age & -0.319 & 0.032 & - & NS \\
\hline BMI & -0.068 & NS & - & NS \\
\hline Diabetes mellitus & -0.115 & NS & - & NS \\
\hline Dyslipidemia & -0.032 & NS & - & NS \\
\hline Current smoker & -0.024 & NS & - & NS \\
\hline \multicolumn{5}{|c|}{ Antihypertensive drugs } \\
\hline ARB/ACEI & 0.083 & NS & - & NS \\
\hline CCB & -0.237 & NS & - & NS \\
\hline$\beta$-Blockers & -0.231 & NS & - & NS \\
\hline Diuretics & 0.092 & NS & - & NS \\
\hline Systolic BP & -0.197 & NS & - & NS \\
\hline Diastolic BP & -0.140 & NS & - & NS \\
\hline Heart rate & 0.049 & NS & - & NS \\
\hline Total cholesterol & 0.267 & NS & - & NS \\
\hline HDL cholesterol & 0.261 & NS & - & NS \\
\hline Triglycerides & -0.020 & NS & - & NS \\
\hline Hemoglobin & 0.153 & NS & - & NS \\
\hline Creatinine & -0.013 & NS & - & NS \\
\hline White cell count & -0.092 & NS & - & NS \\
\hline hsCRP & -0.346 & 0.023 & -0.360 & 0.036 \\
\hline CAVI & -0.338 & 0.023 & - & NS \\
\hline
\end{tabular}

Abbreviations: ACEI, angiotensin-converting enzyme inhibitors; ARB, angiotensin II receptor blockers; BMI, body mass index; BP, blood pressure; CAVI, cardio-ankle vascular index; CCB, calcium channel blockers; HDL, high-density lipoprotein; hsCRP, high-sensitivity C-reactive protein.
Table 3 Correlations between clinical parameters and the percentage of predicted FEV $_{1}$

\begin{tabular}{|c|c|c|c|c|}
\hline & \multicolumn{2}{|c|}{ Univariate } & \multicolumn{2}{|c|}{ Multivariate } \\
\hline & $r$ & $\mathrm{P}$ value & $\beta$ & $\mathrm{P}$ value \\
\hline Age & 0.045 & NS & - & NS \\
\hline BMI & -0.069 & NS & - & NS \\
\hline Diabetes mellitus & -0.216 & NS & - & NS \\
\hline Dyslipidemia & -0.075 & NS & - & NS \\
\hline Current smoker & -0.118 & NS & - & NS \\
\hline \multicolumn{5}{|c|}{ Antihypertensive drugs } \\
\hline ARB/ACEI & -0.222 & NS & - & NS \\
\hline $\mathrm{CCB}$ & -0.077 & NS & - & NS \\
\hline$\beta$-Blockers & -0.141 & NS & - & NS \\
\hline Diuretics & 0.064 & NS & - & NS \\
\hline Systolic BP & -0.242 & NS & - & NS \\
\hline Diastolic BP & -0.378 & 0.011 & -0.354 & 0.037 \\
\hline Heart rate & -0.048 & NS & - & NS \\
\hline Total cholesterol & 0.202 & NS & - & NS \\
\hline HDL cholesterol & 0.174 & NS & - & NS \\
\hline Triglycerides & -0.056 & NS & - & NS \\
\hline Hemoglobin & -0.003 & NS & - & NS \\
\hline Creatinine & -0.083 & NS & - & NS \\
\hline White cell count & -0.208 & NS & - & NS \\
\hline hsCRP & -0.178 & NS & - & NS \\
\hline CAVI & -0.239 & NS & - & NS \\
\hline
\end{tabular}

Abbreviations: ACEI, angiotensin-converting enzyme inhibitors; ARB, angiotensin II receptor blockers; BMI, body mass index; BP, blood pressure; CAVI, cardio-ankle vascular index $\mathrm{CCB}$, calcium channel blockers; HDL, high-density lipoprotein; hsCRP, high-sensitivity C-reactive protein.
FVC correlated with age $(r=-0.319, P=0.032)$, hsCRP $(r=-0.346$, $P=0.023)$ and CAVI $(r=-0.338, P=0.023)$ by linear regression analysis. Stepwise multiple regression analysis indicated that hsCRP ( $\beta=-0.360, P=0.036$ ) was independently associated with the percentage of predicted FVC (Table 2).

The percentage of predicted $\mathrm{FEV}_{1}$ correlated with diastolic blood pressure $(r=-0.378, P=0.011)$ by linear regression analysis. Stepwise multiple regression analysis indicated that diastolic blood pressure ( $\beta=-0.354, P=0.037)$ was independently associated with percentage of predicted $\mathrm{FEV}_{1}$ (Table 3 ).

The $\mathrm{FEV}_{1} / \mathrm{FVC}$ ratio correlated with age $(r=-0.332, P=0.026)$ and CAVI $(r=-0.399, P=0.007)$ by linear regression analysis. Stepwise multiple regression analysis indicated that CAVI $(\beta=-0.418$, $P=0.014)$ was independently associated with the $\mathrm{FEV}_{1} / \mathrm{FVC}$ ratio (Table 4).

The pulmonary age correlated with age $(r=0.553, P<0.001)$, hsCRP $(r=0.314, P=0.040)$ and CAVI $(r=0.559, P<0.001)$ by linear regression analysis. Stepwise multiple regression analysis indicated that CAVI $(\beta=0.514, P=0.002)$ was independently associated with pulmonary age (Table 5$)$.

Comparisons of CAVI between hypertensive patients with normal and increased pulmonary age

The clinical parameters and CAVI were compared between patients with normal and increased pulmonary age (Table 6). The CAVI and hsCRP were significantly higher in patients with increased pulmonary age $\left(9.4 \pm 1.4\right.$ and $\left.0.22 \pm 0.23 \mathrm{mg} \mathrm{dl}^{-1}\right)$ than in those with normal pulmonary age $\left(8.4 \pm 0.9\right.$ and $\left.0.10 \pm 0.11 \mathrm{mg} \mathrm{dl}^{-1}\right) \quad(P=0.011$ and 0.045 , respectively).

\section{DISCUSSION}

Pulmonary function assessed by spirometry can differentiate between restrictive and obstructive defects of ventilator function. ${ }^{25}$ Restrictive ventilatory defects are characterized by decreased FVC. By contrast, obstructive ventilatory defects are characterized by decreased $\mathrm{FEV}_{1} / \mathrm{FVC}$ ratio. This study presents data regarding the relationships between CAVI and pulmonary function in treated hypertensive patients who have been receiving antihypertensive drugs for at least 1 year. The data led us to the following conclusions. First, increased CAVI was not associated with decreased FVC, reflecting a restrictive ventilatory defect, but was associated with a decreased $\mathrm{FEV}_{1} / \mathrm{FVC}$ ratio reflecting an obstructive ventilatory defect. Second, CAVI was an independent predictor of pulmonary age. Finally, hypertensive patients with increased pulmonary age, who have reduced pulmonary function, show increased CAVI values and increased hsCRP levels.

Our data suggest that hypertensive patients with increased arterial stiffness, as assessed by elevated CAVI, may have a risk of COPD. Some previous studies ${ }^{16-19}$ have demonstrated that airflow limitation with decreased predicted $\mathrm{FEV}_{1}$ was associated with atherosclerosis. However, the atherosclerosis in the previous studies was assessed by carotid intima-media thickness and plaque. Our data provide new information regarding the association between obstructive ventilatory defects and increased arterial stiffness. 
Table 4 Correlations between clinical parameters and $\mathrm{FEV}_{1} / \mathrm{FVC}$ ratio

\begin{tabular}{|c|c|c|c|c|}
\hline & \multicolumn{2}{|c|}{ Univariate } & \multicolumn{2}{|c|}{ Multivariate } \\
\hline & $\mathrm{r}$ & $\mathrm{P}$ value & $\beta$ & $\mathrm{P}$ value \\
\hline Age & -0.332 & 0.026 & - & NS \\
\hline BMI & 0.211 & NS & - & NS \\
\hline Diabetes mellitus & -0.188 & NS & - & NS \\
\hline Dyslipidemia & 0.139 & NS & - & NS \\
\hline Current smoker & 0.160 & NS & - & NS \\
\hline \multicolumn{5}{|c|}{ Antihypertensive drugs } \\
\hline ARB/ACEI & -0.204 & NS & - & NS \\
\hline $\mathrm{CCB}$ & 0.011 & NS & - & NS \\
\hline$\beta$-Blockers & 0.070 & NS & - & NS \\
\hline Diuretics & 0.145 & NS & - & NS \\
\hline Systolic BP & -0.228 & NS & - & NS \\
\hline Diastolic BP & -0.226 & NS & - & NS \\
\hline Heart rate & -0.125 & NS & - & NS \\
\hline Total cholesterol & 0.184 & NS & - & NS \\
\hline HDL cholesterol & 0.051 & NS & - & NS \\
\hline Triglycerides & 0.239 & NS & - & NS \\
\hline Hemoglobin & -0.079 & NS & - & NS \\
\hline Creatinine & -0.300 & NS & - & NS \\
\hline White cell count & -0.296 & NS & - & NS \\
\hline hsCRP & -0.031 & NS & - & NS \\
\hline CAVI & -0.399 & 0.007 & -0.418 & 0.014 \\
\hline
\end{tabular}

Abbreviations: ACEI, angiotensin-converting enzyme inhibitors; ARB, angiotensin II receptor blockers; BMI, body mass index; BP, blood pressure; CAVI, cardio-ankle vascular index; CCB, calcium channel blockers; HDL, high-density lipoprotein; hSCRP, high-sensitivity C-reactive protein.

Table 5 Correlations between clinical parameters and pulmonary age

\begin{tabular}{|c|c|c|c|c|}
\hline & \multicolumn{2}{|c|}{ Univariate } & \multicolumn{2}{|c|}{ Multivariate } \\
\hline & $r$ & $\mathrm{P}$ value & $\beta$ & $\mathrm{P}$ value \\
\hline Age & 0.553 & $<0.001$ & - & NS \\
\hline BMI & -0.096 & NS & - & NS \\
\hline Diabetes mellitus & 0.078 & NS & - & NS \\
\hline Dyslipidemia & -0.112 & NS & - & NS \\
\hline Current smoker & -0.063 & NS & - & NS \\
\hline \multicolumn{5}{|c|}{ Antihypertensive drugs } \\
\hline ARB/ACEI & -0.096 & NS & - & NS \\
\hline CCB & 0.190 & NS & - & NS \\
\hline$\beta$-Blockers & 0.168 & NS & - & NS \\
\hline Diuretics & -0.238 & NS & - & NS \\
\hline Systolic BP & 0.291 & NS & - & NS \\
\hline Diastolic BP & 0.138 & NS & - & NS \\
\hline Heart rate & -0.041 & NS & - & NS \\
\hline Total cholesterol & -0.195 & NS & - & NS \\
\hline HDL cholesterol & -0.141 & NS & - & NS \\
\hline Triglycerides & -0.061 & NS & - & NS \\
\hline Hemoglobin & -0.178 & NS & - & NS \\
\hline Creatinine & 0.157 & NS & - & NS \\
\hline White cell count & 0.229 & NS & - & NS \\
\hline hsCRP & 0.314 & 0.040 & - & NS \\
\hline CAVI & 0.559 & $<0.001$ & 0.514 & 0.002 \\
\hline
\end{tabular}

Abbreviations: ACEI, angiotensin-converting enzyme inhibitors; ARB, angiotensin II receptor blockers; BMI, body mass index; BP, blood pressure; CAVI, cardio-ankle vascular index; CCB, calcium channel blockers; HDL, high-density lipoprotein; hsCRP, high-sensitivity C-reactive protein.

Table 6 Comparison of clinical parameters between hypertensive patients with increased and normal pulmonary ages

\begin{tabular}{lccc}
\hline & $\begin{array}{c}\text { Normal } \\
\text { pulmonary age } \\
(\mathrm{n}=20)\end{array}$ & $\begin{array}{c}\text { Increased } \\
\text { pulmonary age } \\
(\mathrm{n}=25)\end{array}$ & P value \\
\hline Age (years) & $67.5 \pm 8.2$ & $71.3 \pm 10.1$ & NS \\
BMI & $24.5 \pm 3.4$ & $24.0 \pm 3.5$ & NS \\
Diabetes mellitus (\%) & 15 & 20 & NS \\
Dyslipidemia & 45 & 33 & NS \\
Current smoker (\%) & 10 & 20 & NS
\end{tabular}

Antihypertensive drugs

\section{ARB/ACEI (\%)}

CCB $(\%)$

$\beta$-Blockers (\%)

Diuretics (\%)

Systolic BP $(\mathrm{mm} \mathrm{Hg})$

Diastolic BP $(\mathrm{mm} \mathrm{Hg})$

Heart rate (beats per $\mathrm{min}$ )

Total cholesterol $\left(\mathrm{mg} \mathrm{dl}^{-1}\right)$

HDL cholesterol $\left(\mathrm{mgdl}^{-1}\right)$

Triglycerides $\left(\mathrm{mgdl}^{-1}\right)$

Hemoglobin $\left(\mathrm{g} \mathrm{dl}^{-1}\right)$

Creatinine $\left(\mathrm{mg} \mathrm{dl}^{-1}\right)$

White cell count (cells per $\mu$ )

hsCRP (mgdl-1)

CAVI Abbreviations: ACEI, angiotensin-converting enzyme inhibitors; ARB, angiotensin II receptor
blockers; BMI, body mass index; BP, blood pressure; CAVI, cardio-ankle vascular index; CCB, calcium channel blockers; HDL, high-density lipoprotein; hSCRP, high-sensitivity $\mathrm{C}$-reactive protein.

Recently, COPD has been recognized as a systemic disease, ${ }^{26,27}$ and the association between COPD and cardiovascular disease has received attention. ${ }^{28}$ COPD is characterized by chronic airflow limitation from an inappropriate and excessive inflammatory response of the lungs to respiratory pollutants, mainly tobacco smoking. ${ }^{29}$ Recent studies have suggested that an important clue to the mechanism linking increased cardiovascular disease and COPD is persistent low-grade systemic inflammation as indicated by elevated levels of CRP observed in patients with COPD. ${ }^{30,31} \mathrm{CRP}$ levels are associated with cardiovascular risk in the general population ${ }^{32,33}$ and poor prognosis in patients with COPD. ${ }^{34}$ Various studies have found CRP has a causal role in atherosclerosis, ${ }^{35,36}$ metabolic syndrome, ${ }^{37}$ coronary heart disease and ischemic heart failure. ${ }^{38}$ Thus, CRP has been increasingly investigated as a promising therapeutic target for the prevention of cardiovascular disease. ${ }^{39}$ Our data regarding high-sensitivity CRP (hsCRP) are in agreement with these previous studies. ${ }^{30-39}$ Actually, hypertensive patients with increased pulmonary age showed increased hsCRP and CAVI compared with those with normal pulmonary age (Table 6). Therefore, low-grade systemic inflammation may have led to an association between arterial stiffness and pulmonary function in the present study.

Several limitations exist in the present study. First, both CAVI and pulmonary function are influenced by aging. Therefore, we performed stepwise multiple regression analysis to identify the independent determinants of the parameters of the pulmonary function test and found that increased CAVI was an independent determinant of $\mathrm{FEV}_{1} / \mathrm{FVC}$ ratio (Table 4). However, the present study is limited by relatively small sample size of the patients. Further studies, including larger 
numbers of patients, are needed to confirm that increased CAVI is an independent determinant of pulmonary function. Second, the majority of patients in the present study did not show severe pulmonary dysfunction, which was assessed by the percentage of predicted FVC, percentage of predicted $\mathrm{FEV}_{1}$ and FEV1/FVC ratio (Table 1). Further studies, including larger numbers of patients with more severe pulmonary dysfunction, are needed to validate the association between CAVI and pulmonary function.

In conclusion, increased arterial stiffness is associated with reduced pulmonary function, which is assessed by $\mathrm{FEV}_{1} / \mathrm{FVC}$ ratio, in hypertensive patients. Arterial stiffness, as assessed by CAVI, is correlated with pulmonary age, which has been proposed by the Japanese Respiratory Society as a measure to detect early-stage COPD. Therefore, hypertensive patients with high CAVI may be paid extra attention to monitor the progression of COPD.

\section{CONFLICT OF INTEREST}

The authors declare no conflict of interest.

1 Blacher J, Asmar R, Djane S, London GM, Safar ME. Aortic pulse wave velocity as a marker of cardiovascular risk in hypertensive patients. Hypertension 1999; 33: 1111-1117.

2 Laurent S, Boutouyrie P, Asmar R, Gautier I, Laloux B, Guize L, Ducimetiere P, Benetos A. Aortic stiffness is an independent predictor of all-cause and cardiovascular mortality in hypertensive patients. Hypertension 2001; 37: 1236-1241.

3 Shirai K, Utino J, Otsuka K, Takata M. A novel blood pressure-independent arterial wall stiffness parameter; cardio ankle vascular index (CAVI). J Atheroscler Thromb 2006; 13: 101-107.

4 Shirai K. Analysis of vascular function using the cardio-ankle vascular index (CAVI). Hypertens Res 2011; 34: 684-685.

5 Nakamura K, Tomaru T, Yamamura S, Miyashita Y, Shirai K, Noike H. Cardio-ankle vascular index is a candidate predictor of coronary atherosclerosis. Circ J 2008; 72: 598-604.

6 Takaki A, Ogawa H, Wakeyama T, Iwami T, Kimura M, Hadano Y, Matsuda S, Miyazaki Y, Matsuda T, Hiratsuka A, Matsuzaki M. Cardio-ankle vascular index is a new noninvasive parameter of arterial stiffness. Circ J 2007; 71: 1710-1714.

7 Nakamura K, lizuka T, Takahashi M, Shimizu K, Mikamo H, Nakagami T, Suzuki M, Hirano K, Sugiyama Y, Tomaru T, Miyashita Y, Shirai K, Noike H. Association between cardio-ankle vascular index and serum cystatin $\mathrm{C}$ levels in patients with cardiovascular risk factor. J Atheroscler Thromb 2009; 16: 371-379.

8 Masugata H, Senda S, Okuyama H, Murao K, Inukai M, Hosomi N, Yukiiri K, Nishiyama A, Kohno M, Goda F. Comparison of central blood pressure and cardio-ankle vascular index for association with cardiac function in treated hypertensive patients. Hypertens Res 2009; 32: 1136-1142.

9 Ibata J, Sasaki H, Kakimoto T, Matsuno S, Nakatani M, Kobayashi M, Tatsumi K, Nakano Y, Wakasaki H, Furuta H, Nishi M, Nanjo K. Cardio-ankle vascular index measures arterial wall stiffness independent of blood pressure. Diabetes Res Clin Pract 2008; 80: 265-270.

10 Noike H, Nakamura K, Sugiyama Y, lizuka T, Shimizu K, Takahashi M, Hirano K, Suzuki M, Mikamo H, Nakagami T, Shirai K. Changes in cardio-ankle vascular index in smoking cessation. J Atheroscler Thromb 2010; 17: 517-525.

11 Murray CJ, Lopez AD. Global mortality, disability, and the contribution of risk factors: Global Burden of Disease Study. Lancet 1997; 349: 1436-1442.

12 Rabe KF, Hurd S, Anzueto A, Barnes PJ, Buist SA, Calverley P, Fukuchi Y, Jenkins C, Rodriguez-Roisin R, van Weel C, Zielinski J, Global Initiative for Chronic Obstructive Lung Disease. Global strategy for the diagnosis, management, and prevention of chronic obstructive pulmonary disease: GOLD executive summary. Am J Respir Crit Care Med 2007; 176: 532-555.

13 Camilli AE, Robbins DR, Lebowitz MD. Death certificate reporting of confirmed airways obstructive disease. Am J Epidemiol 1991; 133: 795-800.

14 Anthonisen NR, Connett JE, Enright PL, Manfreda J, Lung Health Study Research Group. Hospitalizations and mortality in the Lung Health Study. Am J Respir Crit Care Med 2002; 166: 333-339.
15 Calverley PM, Anderson JA, Celli B, Ferguson GT, Jenkins C, Jones PW, Yates JC, Vestbo J, TORCH investigators. Salmeterol and fluticasone propionate and survival in chronic obstructive pulmonary disease. N Engl J Med 2007; 356: 775-789.

16 Zureik M, Kauffmann F, Touboul PJ, Courbon D, Ducimetière P. Association between peak expiratory flow and the development of carotid atherosclerotic plaques. Arch Intern Med 2001; 161: 1669-1676.

17 Engström G, Hedblad B, Valind S, Janzon L. Asymptomatic leg and carotid atherosclerosis in smokers is related to degree of ventilatory capacity: longitudinal and cross-sectional results from 'Men born in 1914', Sweden. Atherosclerosis 2001; 155: 237-243.

18 Schroeder EB, Welch VL, Evans GW, Heiss G. Impaired lung function and subclinical atherosclerosis. The ARIC study. Atherosclerosis 2005; 180: 367-373.

19 Iwamoto H, Yokoyama A, Kitahara Y, Ishikawa N, Haruta Y, Yamane K, Hattori N, Hara H, Kohno N. Airflow limitation in smokers is associated with subclinical atherosclerosis. Am J Respir Crit Care Med 2009; 179: 35-40.

20 Zureik M, Benetos A, Neukirch C, Courbon D, Bean K, Thomas F, Ducimetière $P$. Reduced pulmonary function is associated with central arterial stiffness in men. $\mathrm{Am} \mathrm{J}$ Respir Crit Care Med 2001; 164: 2181-2185.

21 Sabit R, Bolton CE, Edwards PH, Pettit RJ, Evans WD, McEniery CM, Wilkinson IB, Cockcroft JR, Shale DJ. Arterial stiffness and osteoporosis in chronic obstructive pulmonary disease. Am J Respir Crit Care Med 2007; 175: 1259-1265.

22 Tomiyama H, Yamashina A. CAVI vs pressure and stiffness gradients in the arterial tree. Hypertens Res 2010; 33: 380.

23 The Japanese Respiratory Society. Guideline for the Diagnosis and Treatment of COPD (Chronic Obstructive Pulmonary Disease, 2nd edn Medical Review: Tokyo, 2004 pp. 1-36.

24 American Thoracic Society. Standardization of spirometry, 1994 update. Am J Respir Crit Care Med 1995; 152: 1107-1136.

25 Paraskeva MA, Borg BM, Naughton MT. Spirometry. Aust Fam Physician 2011; 40: 216-219.

26 Punturieri A, Croxton TL, Weinmann GG, Kiley JP. Chronic obstructive pulmonary disease: a view from the NHLBI. Am J Respir Crit Care Med 2008; 178: 441-443.

27 Fabbri LM, Luppi F, Beghé B, Rabe KF. Complex chronic comorbidities of COPD. Eur Respir J 2008; 31: 204-212.

28 Maclay JD, McAllister DA, Macnee W. Cardiovascular risk in chronic obstructive pulmonary disease. Respirology 2007; 12: 634-641.

29 MacNee W. Pathogenesis of chronic obstructive pulmonary disease. Proc Am Thorac Soc 2005; 2: 258-266

30 Sin DD, Man SF. Why are patients with chronic obstructive pulmonary disease at increased risk of cardiovascular diseases? The potential role of systemic inflammation in chronic obstructive pulmonary disease. Circulation 2003; 107: 1514-1519.

31 Sin DD, Man SF. Systemic inflammation and mortality in chronic obstructive pulmonary disease. Can J Physiol Pharmacol 2007; 85: 141-147.

32 Ridker PM, Hennekens $\mathrm{CH}$, Buring JE, Rifai N. C-reactive protein and other markers of inflammation in the prediction of cardiovascular disease in women. $N$ Eng/ J Med 2000; 342: 836-843.

33 Olsen MH, Hansen TW, Christensen MK, Gustafsson F, Rasmussen S, Wachtell K, Ibsen H, Torp-Pedersen C, Hildebrandt PR. Cardiovascular risk prediction by $\mathrm{N}$-terminal pro brain natriuretic peptide and high sensitivity $\mathrm{C}$-reactive protein is affected by age and sex. J Hypertens 2008; 26: 26-34.

34 Man SF, Connett JE, Anthonisen NR, Wise RA, Tashkin DP, Sin DD. C-reactive protein and mortality in mild to moderate chronic obstructive pulmonary disease. Thorax 2006; 61: 849-853.

35 Torzewski J, Torzewski M, Bowyer DE, Fröhlich M, Koenig W, Waltenberger J, Fitzsimmons C, Hombach V. C-reactive protein frequently colocalizes with the terminal complement complex in the intima of early atherosclerotic lesions of human coronary arteries. Arterioscler Thromb Vasc Biol 1998; 18: 1386-1392.

36 Zwaka TP, Hombach V, Torzewski J. C-reactive protein-mediated low density lipoprotein uptake by macrophages: implications for atherosclerosis. Circulation 2011; 103: 1194-1197.

37 Ridker PM, Buring JE, Cook NR, Rifai N. C-reactive protein, the metabolic syndrome, and risk of incident cardiovascular events: an 8-year follow-up of 14,719 initially healthy American women. Circulation 2003; 107: 391-397.

38 Kardys I, Knetsch AM, Bleumink GS, Deckers JW, Hofman A, Stricker BH, Witteman JC C-reactive protein and risk of heart failure. The Rotterdam study. Am Heart J 2006; 152: 514-520.

39 Pepys MB, Hirschfield GM, Tennent GA, Gallimore JR, Kahan MC, Bellotti V, Hawkins PN, Myers RM, Smith MD, Polara A, Cobb AJ, Ley SV, Aquilina JA, Robinson CV, Sharif I, Gray GA, Sabin CA, Jenvey MC, Kolstoe S, Thompson D, Wood SP. Targeting C-reactive protein for the treatment of cardiovascular disease. Nature 2006; 440: 1217-1221. 